\title{
Phenological features of the growth and development of Itoh Group peony cultivars in the conditions of the M. M. Gryshko National Botanical Garden of the National Academy of Sciences of Ukraine
}

\author{
T. 0. Shcherbakova*, V. F. Gorobets \\ M. M. Gryshko National Botanical Garden, NAS of Ukraine, 1 Tymiriazievska St., Kyiv, 03004, Ukraine, \\ "e-mail: Shcherbacova@ukr.net
}

Purpose. To reveal the peculiarities of the seasonal rhythm of growth and development of Itoh Group peony cultivars in the conditions of the M. M. Gryshko National Botanical Garden of the National Academy of Sciences of Ukraine. Methods. The objects of research were plants of 24 cultivars of Itoh Group peonies. The research was conducted on the experimental field of the Department of Flowering and Ornamental Plants of the M. M. Gryshko National Botanical Garden of the National Academy of Sciences of Ukraine during 2017-2020. The sum of effective temperatures was calculated by summing the daily air temperatures reduced by the biological zero. Results. The phenological phases of Ito Group cultivars growth were determined. Phenological spectra for different groups are presented. It was determined that the flowering of early cultivars: 'First Arrival', 'Hillary', 'Julia Rose', 'Morning Lilac', 'Old Rose Dandy', 'Sonoma Apricot' starts at the sum of effective temperatures $\geq 400^{\circ} \mathrm{C}$. The middle group hybrids bloom when the sum of temperatures reaches $450^{\circ} \mathrm{C}$. This group includes: 'Bartzella', 'Callie's Memory', 'Cora Louise', 'Lollipop', 'Scarlet Heaven', 'Sonoma Velvet Ruby', 'Yellow Dream', 'Yellow Emperor', 'Yellow Heaven', 'Yellow Waterlily'. Late flowering group includes: 'Border Charm', 'Garden Treasure', 'Kopper Kettle', 'Pastel Splendor', 'Prairie Charm', 'Viking Full Moon', 'White Emperor', 'Yankee Doodle Dandy'; accumulation of effective temperatures above $500^{\circ} \mathrm{C}$ is an essential requirement for their flowering. Conclusions. Itoh Group cultivars successfully pass all phases of seasonal development and manage to complete the growing season. Cultivars belong to the spring-summer-autumngreen phenorhythmotype. The onset of the corresponding phenological phases in peonies of the studied group of cultivars requires a certain sum of effective temperatures. Plant outgrowth begins on March 23 - April 2, when the sum of effective temperatures ranges from $20-40{ }^{\circ} \mathrm{C}$. The flowering of cultivars characterized as late spring, lasts $6-9$ days $\pm 3-4$ days, depending on the varietal characteristics and the year of cultivation. A rapid increase in the sum of effective temperatures up to $700{ }^{\circ} \mathrm{C}$ shortens the flowering phase by $4-5$ days. An assortment of early (May 22-25 $\pm 2-3$ days), medium (May 26-28 $\pm 3-5$ days) and late-flowering (May 29-31 \pm 4-6 days) cultivars has been selected, what ensures the continuity of peony flowering during two months.

Keywords: peonies Itoh Group; phenological phases; sum of effective temperatures.

\section{Introduction}

An important indicator of the successful adaptation of plants is the compliance of their seasonal development with the meteorological conditions of the introduction area. Elucidation of the peculiarities of the passage of the growth and development phases of introduced species will make it possible not only to predict their behavior in new conditions, but also determine the economic and biological characteristics of the culture, highlight promising species and cultivars, and select an assortment.

Nowadays, peony cultivars of the new Itoh Group, created on the basis of crossing plants of various life forms: grasses, bushes, semi-bushes, are being actively introduced into ornamental

\footnotetext{
Tetiana Shcherbakova

http://orcid.org/0000-0003-1763-6841

Vasyl Gorobets

http://orcid.org/0000-0001-6315-9033
}

gardening. To obtain Itoh Group cultivars herbaceous cultivars of the Lactiflora Gp are used as a maternal component, and semi-shrubs of the Lutea Hybrid Gp variety and bush forms of Suffruticosa Gp [1-3] are used as a paternal one. The result of interspecific hybridization is manifested in the life form of Ito hybrids, characteristics of their growth and development, and reproductive ability. Plants combine the characteristics of both life forms. Signs of herbaceous forms appear in the stems, which die off in winter. From a group of bush peonies they received the shape of flowers and leaves $[4,5]$.

Now in the Registry of Peony Cultivars of the American Peony Society, 145 cultivars of the Itoh group are registered [6]. Studies on their introduction have shown its promise due to high decorative characteristics and a wide range of ecological plasticity in comparison with parental species [7-9].

The cultivars entered Ukraine over the past ten years and are cultivated in separate collections of botanical gardens, arboretums and 
amateur flower growers. The most representative in terms of assortment is the collection of peonies of the M. M. Gryshko National Botanical Garden of the National Academy of Sciences of Ukraine (NBG), on the basis of which studies on introduction and variety assessment are now being carried out. Preliminary studies show that under NBG conditions the cultivars retain all their decorative properties [10, 11]. However, it would be advisable to trace in detail the timing of the passage of plant growth and development phases and their dependence on environmental conditions.

The aim of the research is to reveal the features of the seasonal growth and development rhythm of the Itoh Gp peony cultivars under the conditions of the NBG.

\section{Materials and methods}

Plants of 24 Itoh Gp peony cultivars from the NBG collection were the objects of research (Table 1). The cultivars entered the collection by exchanging and buying planting material as parts of rhizomes with 3-4 germinal shoots from amateur flower growers and garden centers in Ukraine and neighboring countries. Since peonies are perennial plants that can grow without transplanting in one place from 20 to 30 years and bloom stably every year, 12 plants of each variety were planted for research (4 pcs. in replication). To identify cultivars, all available descriptions and descriptions of cultivars given in the register of the American Peony Society were used [6].

\begin{tabular}{|c|c|c|}
\hline No & Cultivars name, author and year of registration & Year of introduction, registration number \\
\hline 1 & 'Bartzella' (Anderson, R. F., 1986) & 2008,377199 \\
\hline 2 & 'Border Charm' (Hollingsworth, 1984) & 2014,377201 \\
\hline 3 & ‘Callie's Memory' (Anderson, R. F., 1999) & 2009,377202 \\
\hline 4 & ‘Cora Louise' (Anderson, R. F., 1986) & 2009,377204 \\
\hline 5 & 'First Arrival' (Anderson, R. F., 1986) & 2014,377268 \\
\hline 6 & ‘Garden Treasure' (Hollingsworth, 1984) & 2014,377269 \\
\hline 7 & ‘Hillary' (Anderson, R. F., 1990) & 2009,377213 \\
\hline 8 & 'Julia Rose' (Anderson, R. F., 1989) & 2009,377215 \\
\hline 9 & ‘Kopper Kettle' (Anderson, R. F., 1999) & 2009,377203 \\
\hline 10 & ‘Lollipop' (Anderson, R. F., 1999) & 2014,377228 \\
\hline 11 & 'Morning Lilac' (Anderson, R. F., 1999) & 2014,377232 \\
\hline 12 & ‘Old Rose Dandy' (Laning, 1993) & 2016,383639 \\
\hline 13 & ‘Pastel Splendor' (Anderson, R. F. / Seidl, Wm, 1996) & 2014,377337 \\
\hline 14 & 'Prairie Charm' (Hollingsworth, 1992) & 2014,377242 \\
\hline 15 & 'Scarlet Heaven' (Anderson, R. F., 1999) & 2014,377246 \\
\hline 16 & 'Sonoma Apricot' (Tolomeo, 1999) & 2014,377284 \\
\hline 17 & 'Sonoma Velvet Ruby' (Tolomeo, 1999) & 2014,377285 \\
\hline 18 & 'Viking Full Moon' (Pehrson / Seidl, 1989) & 2012,377254 \\
\hline 19 & 'White Emperor' (Seidl, 1989) & 2014,377256 \\
\hline 20 & 'Yankee Doodle Dandy' (Smith, D. R., 2002) & 2016,383638 \\
\hline 21 & 'Yellow Dream' (Itoh / Smirnow, 1974) & 2011,377259 \\
\hline 22 & 'Yellow Emperor' (Itoh / Smirnow, 1974) & 2011,377260 \\
\hline 23 & 'Yellow Heaven' (Itoh / Smirnow, 1974) & 2011,377261 \\
\hline 24 & 'Yellow Waterlily' (Anderson, R. F., 1999) & 2014,377292 \\
\hline
\end{tabular}

The studies were carried out at the experimental site of the Department of Flowering and Ornamental Plants of the NBG during 2017-2020. The site of peonies is located on the Pechersk slopes of the Kyiv Upland in the "Zvirynets" stow $\left(50^{\circ} 32^{\prime} \mathrm{N}\right.$ and $\left.30^{\circ} 33^{\prime} \mathrm{E}\right)$ in the southeastern part of Kyiv on the border of two physical and geographical zones: Polissia and Forest-Steppe.

The climate is temperate continental. The average annual air temperature is $9.5{ }^{\circ} \mathrm{C}$. In 2017 it was $9.8{ }^{\circ} \mathrm{C}$, in $2018-9.5^{\circ} \mathrm{C}$, in 2019 and $2020-10.6$ and $10.9{ }^{\circ} \mathrm{C}$, respectively. Un- der the research conditions, thaws were observed in winter, sometimes with an increase in temperature up to $5{ }^{\circ} \mathrm{C}[12,13]$.

In Kyiv, the annual course of air temperature is somewhat delayed compared to the course of solar radiation. The most intense increase in air temperature occurs from March to April (by $8.0^{\circ} \mathrm{C}$ ) and from April to May (by $6.2^{\circ} \mathrm{C}$ ). Summer weather prevails in May. So, the average temperature in May 2017 was $15.2^{\circ} \mathrm{C}$, in $2018-18.8{ }^{\circ} \mathrm{C}$, in $2019-17.0{ }^{\circ} \mathrm{C}$. However, May 2020 turned out to be quite cold with an average daily temperature of $12.4{ }^{\circ} \mathrm{C}$. From 
July, a gradual decrease in temperature began, which became more intense from September $[13,14]$.

In the seasonal rhythm of plant growth and development, the most significant are phases of spring sprouting, flowering and the duration of their passage by plants [15]. The timing of the phenological phases of growth and development in the studied plants was determined by conventional methods [16]. The beginning of the following phenological phases was recorded: sprouting (opening of buds and the beginning of shoot growth), unfolding of leaves (the leaf blade acquires its characteristic shape, but still does not reach its normal size), budding (the scales of a flower bud diverge and the bud is visible with the naked eye), flowering (opening of single flowers), the end of the growing season (the appearance of leaves with a changed color). In addition, the duration of the growing season and the duration of cultivars flowering were determined.

The peculiarities of shoots formation were studied according to F. M. Kuperman [17]. The effective temperatures sum was calculated by summing the daily air temperatures, reduced by the value of the biological zero. Statistical processing of the results was carried out according to G. M. Zaytsev's [18] method with using Microsoft Excel.

\section{Results and discussion}

The works of Yu. D. Mishchykhina [8], S. V. Efimov, G. V. Degtyareva [9], A. A. Reut [19] are devoted to the study of the phenological aspects of the growth and development of Itoh Gp peonies. They found that under the conditions of the botanical garden of Moscow State University, the Middle Urals and the Republic of Bashkortostan, cultivars of this group go through all phenological phases of development. Shevkun A. G. [20, 21] notes that in the soil and climatic conditions of Moscow region, shoots sprouting of the cultivars 'Bartzella', 'Garden Treasure', 'Hillary, 'Prairie Charm', 'Yellow Heaven' begins on April 9-10 and lasts until April 25. Flowering begins in the 1st2nd decade of June. The duration of flowering is 13-15 days, and the duration of the growing season is 194-200 days. For the eastern region of Central China G. Wu, L. Cui, Sh. Liu et al. [7] noted long and abundant flowering of 16 cultivars of Itoh Gp peonies from early to late May.

Our observations on the growth and development of Itoh group peonies in Kyiv showed that the shoots spring sprouting begins in the second half of March. During this period, the intensity of solar radiation increases most, the air temperature rises and the soil surface warms up. So, if in Kyiv conditions in March the average monthly air temperature in 2017 was $6.2{ }^{\circ} \mathrm{C}$, in $2018-1.9{ }^{\circ} \mathrm{C}$, in $2019-5.1{ }^{\circ} \mathrm{C}$, in $2020-6.5{ }^{\circ} \mathrm{C}$, then in April it increased already up to $10.4{ }^{\circ} \mathrm{C}, 13.1{ }^{\circ} \mathrm{C}, 10.6{ }^{\circ} \mathrm{C}$ and $9.9^{\circ} \mathrm{C}$, respectively.

When cultured the soil and water regimes can be regulated, so the main factors that will affect the growth and development of plants is solar radiation and air temperature. It is known that the development of plants begins only when the average daily temperature exceeds their biological zero, which is $5{ }^{\circ} \mathrm{C}$ for peonies.

It was revealed that the phase of spring shoots sprouting in early peony cultivars in 2017 began on March 22, in 2019 - on March 20. The sum of effective temperatures on these days was 24.7 and $21.7^{\circ} \mathrm{C}$, respectively (Fig. 1). Since March 2018 was characterized by an average temperature of $-1.9{ }^{\circ} \mathrm{C}$, which was a deviation from the norm of $-3.7^{\circ} \mathrm{C}$, and the average daily temperature began to exceed the biological zero only on April 1, plant sprouting began in early April.

The spring of 2020 , on the other hand, was extremely early. A stable transition of air temperature through $5{ }^{\circ} \mathrm{C}$ was observed already in early March, average daily temperatures were growing rapidly. If on March 3 the sum of effective temperatures was $3.3^{\circ} \mathrm{C}$, then on March 10 it was already $28.1{ }^{\circ} \mathrm{C}$, and on March 18 it was $40.9{ }^{\circ} \mathrm{C}$.

It should be noted that in 2020, some of early cultivars of the collection began to sprout as early as on March 15 ('Morning Lilac', 'Sonoma Apricot'). Late cultivars began to grow only on March 26-28, which was obviously due to night frosts, cold snaps and a drop in the average daily temperature below the biological zero from 22 till 25 March.

It was determined that duriing four years of observation on average the sprouting phase for cultivars 'Bartzella', 'Cora Louise', 'First Arrival', 'Hillary', 'Julia Rose', 'Lollipop', 'Morning Lilac' 'Old Rose Dandy', 'Scarlet Heaven', 'Sonoma Apricot', 'Yellow Dream', 'Yellow Emperor', 'Yellow Heaven', 'Yellow Waterlily' started on March 23-27 $\pm 6-8$ days with the sum of effective temperatures over $20{ }^{\circ} \mathrm{C}$, and for cultivars 'Border Charm', 'Callie's Memory', 'Garden Treasure', 'Kopper Kettle', 'Pastel Splendor', 'Prairie Charm', 'Sonoma Velvet Ruby', 'Viking Full Moon', 'White Emperor', 'Yankee Doodle Dandy' - March 28 - April 2 \pm 4-6 days, when the sum of effective tem- 


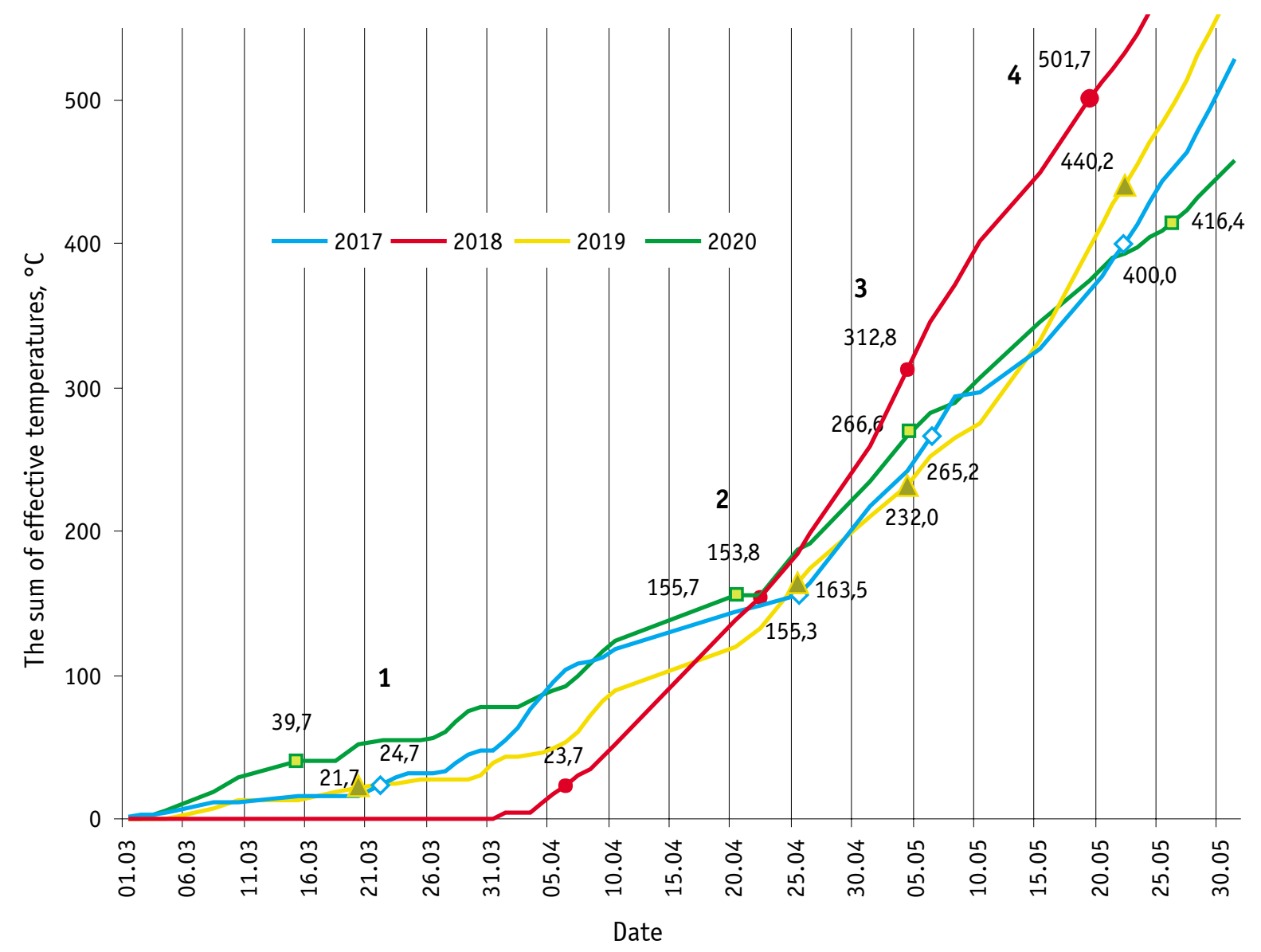

Fig. 1. Variability of the onset of phenological phases of development of early cultivars of Itoh Group peonies depending on the sum of effective air temperatures: 1 - sprouting phase, 2 - leaf unfolding, 3 - budding, 4 - flowering

peratures exceeded $30{ }^{\circ} \mathrm{C}$. The standard deviation for late cultivars was lower than for early ones, due to the more stable accumulation of the effective temperature sum in different years of their growing season.

In the third decade of April, an active growth of peony shoots was noted. Their height during this period was $17-27 \mathrm{~cm}$. The studied plants enter the phase of leaf unfolding at the sum of effective temperatures of 153.8-163.5 ${ }^{\circ} \mathrm{C}$. For early sprouting cultivars, it began on April 23-25 $\pm 2-3$, for late April 26-28 \pm 2 days.

Plant budding was observed in the first ten days of May and lasted 16-20 days. In 20182020 plants entered the budding phase on May 4 at the sum of effective temperatures of $232.0-312.8^{\circ} \mathrm{C}$, and in 2017 on May 6 (the sum of effective temperatures was $265.2{ }^{\circ} \mathrm{C}$ ).

Flowering occurred in the 3rd decade of May, on the 60-64th day of plant vegetation. In 2017, the beginning of flowering of early cultivars was recorded on May 22, in 2019 and 2020 - on May 22 and 26, respectively. Although in 2018 the vegetation of plants began quite late, however, due to the sharp accumula- tion of effective temperatures in the first half of May, the flowering of early cultivars began on May 19.

The beginning of the onset of the flowering phase made it possible to divide the Itoh Gp cultivars into three phenological groups: early blooming (May 22-25 $\pm 2-3$ days), midseason blooming (May 26-28 \pm 3-5 days) and late blooming (May 29-31 \pm 4-6 days) (Table 2, Fig. 2).

The beginning of plants flowering is associated with the beginning of the growing season. Early and midseason blooming cultivars were characterized by early sprouting.

Observations showed that early blooming cultivars begin to blossom at the effective temperatures sum of $\geq 400{ }^{\circ} \mathrm{C}$. Cultivars of the middle group bloom when the sum of temperatures reaches $450{ }^{\circ} \mathrm{C}$. The cultivars of the late group begin to bloom when the sum of effective temperatures is $500{ }^{\circ} \mathrm{C}$.

The cultivars of the studied group occupy an intermediate position in comparison with the cultivars of other garden groups of peonies according to the beginning of flowering. So, the onset of the flowering phase of Suffruti- 
Classification of Itoh Group peony cultivars by the beginning of flowering

\begin{tabular}{|l|l|}
\hline \multicolumn{1}{|c|}{ Phenological group } & \multicolumn{1}{c|}{ Cultivars } \\
\hline $\begin{array}{l}\text { Early blooming cultivars } \\
\text { (22-25 May } \pm 2-3 \text { days) }\end{array}$ & 'First Arrival', 'Hillary', 'Julia Rose', 'Morning Lilac', 'Old Rose Dandy', 'Sonoma Apricot' \\
\hline $\begin{array}{l}\text { Midseason blooming cultivars } \\
\text { (26-28 May } \pm 3-5 \text { days) }\end{array}$ & $\begin{array}{l}\text { 'Bartzella', 'Callie's Memory', 'Cora Louise', 'Lollipop', 'Scarlet Heaven', 'Yellow Dream', } \\
\text { 'Yellow Emperor', 'Yellow Heaven', 'Sonoma Velvet Ruby', 'Yellow Waterlily' }\end{array}$ \\
\hline $\begin{array}{l}\text { Late blooming cultivars } \\
\text { (29-31 May } \pm 4-6 \text { days) }\end{array}$ & $\begin{array}{l}\text { 'Border Charm', 'Garden Treasure', 'Kopper Kettle', 'Pastel Splendor', 'Prairie Charm', } \\
\text { 'Viking Full Moon', 'White Emperor', 'Yankee Doodle Dandy' }\end{array}$ \\
\hline
\end{tabular}

cosa Gp cultivars in Kyiv is observed on May 6-10, Herbaceous Hybrid Gp - May 12-14, Lutea Hybrid Gp - May 18-20. Lactiflora Gp cultivars bloom en masse in the first half of June, while Itoh Gp cultivars bloom massively at the end of May. At this time, they ensure the continuity of the flowering of peonies in general from May to June - for two months.

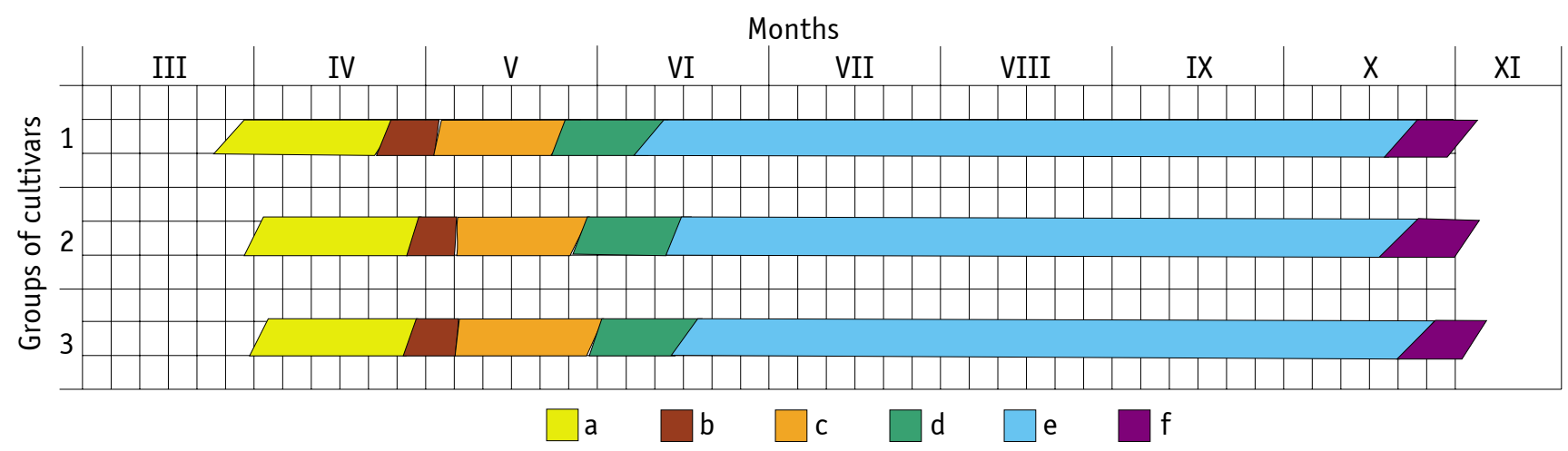

Note. Phenological phases: $\mathrm{a}$ - sprouting; $\mathrm{b}$ - leaf unfolding; $\mathrm{c}$ - budding; $\mathrm{d}$ - flowering; $e-$ vegetation; $f$ - end of vegetation.

Fig. 2. Phenological spectra of the growth and development of the introduced cultivars of Itoh Group peonies during the growing season from III till $X$ months:

1 - early blooming, 2 - midseason blooming, 3 - late blooming cultivars

Plants flowering phase lasted 9-16 days \pm 3-4 days. It depended on the varietal characteristics of plants and was determined by the productivity of flowering. Flowering productivity in the third year of cultivation ranged from $4.5 \pm 1.5$ to $16.0 \pm 3.0$ generative shoots per plant. In the fourth year of cultivation, productivity growth was recorded by 20.2$44.4 \%$. At the same time, it ranged from 6.5 \pm 2.0 to $20.0 \pm 2.5$ shoots per plant. In general, high flowering performance and its duration during observation were shown by cultivars: 'Sonoma Apricot', 'Hillary', 'Bartzella', 'Morning Lilac', 'Lollipop', 'First Arrival'. The smallest number of generative shoots formed 'Pastel Splendor', 'Sonoma Velvet Ruby', 'White Emperor', 'Callie's Memory', 'Prairie Charm'. In the cultivars 'Border Charm', 'Cora Louise', 'Garden Treasure', 'Julia Rose', 'Kooper Kettle', 'Old Rose Dandy, 'Scarlet Heaven', Viking Full Moon', 'Yankee Doodle Dandy', 'Yellow Dream', 'Yellow Emperor', 'Yellow Heaven', 'Yellow Waterlily' flowering performance ranged from 9.5-13,5 shoots per plant.
Rapid increase of the effective temperature sum during plants flowering also influenced its duration. So, in 2018, the duration of cultivars flowering was 4-5 days less compared to 2019. A sharp increase in the effective temperature sum of more than $700{ }^{\circ} \mathrm{C}$ at the beginning of June 2018 led to the end of the flowering phase in early blooming cultivars already on June 5 .

After the end of the flowering phase, the plants continue their growing season, maintaining their decorative effect until the end of October - early November. In general, the growing season was 218-225 days.

Plants entered the state of winter dormancy with 2-4 renewal buds laid on the rhizome part of each monocarpic shoot. Growth cones of vegetative-generative buds at the end of the growing season of mother plants were in a generative state: the germs of perianth parts, stamens and pistil were present. In addition to fully formed renewal buds, in the axils of the leaves of the lower lignified part of the stem and in the zone of shortened internodes of the rhizome, from 1 to 6 dormant buds were formed. 


\section{Conclusions}

The observation results showed that Itoh Gp peony cultivars in the conditions of the M. M. Gryshko National Botanical Garden of NAS of Ukraine successfully pass all phases of seasonal development and complete the growing season. By the duration of the growing season, they belong to the spring-summer-autumngreen phenorhythmotype.

The onset of the corresponding phenological phases in peonies of the studied group of cultivars requires a certain effective temperature sum. So, the growth of cultivars begins on March 23 - April 2, when the sum of effective temperatures ranges from $20-40{ }^{\circ} \mathrm{C}$. Plants enter the leaf unfolding phase when the total effective temperatures are $153.8-163.5^{\circ} \mathrm{C}$. For early sprouting cultivars, it is recorded on April 23-25 $\pm 2-3$, for late April 26-28 \pm 2 days. Plant budding was observed in the 1st decade of May, flowering in the 2nd-3rd decade of May at the sums of effective temperatures of $232.0-312.8{ }^{\circ} \mathrm{C}$, and $400-500{ }^{\circ} \mathrm{C}$, respectively.

The flowering of cultivars is characterized as late spring, lasts $9-16$ days $\pm 3-4$ days, depending on the varietal characteristics of the plants and the year of cultivation. The rapid increase in the sum of effective temperatures up to $700{ }^{\circ} \mathrm{C}$ during flowering reduces its duration by $4-5$ days.

Analysis of the phenological spectra of plant seasonal development made it possible to identify an assortment of early (May 22-25 $\pm 2-3$ days), medium (May 26-28 $\pm 3-5$ days) and late flowering (May 29-31 \pm 4-6 days) Itoh Group peonies, what ensures the continuity of peony flowering during two months.

\section{References}

1. Halda, J. J. (2004). The genus Paeonia. Portland, OR: Timber Press.

2. Page, M. (2005). Paeonia Itoh hybrids. The Plantsmen, 4, 36-39. Retrieved from http://frosthillfarm.homestead.com/PeonyItoyblurb.pdf

3. Kamenetsky, R., \& Dole, J. (2012). Herbaceous peony (Paeonia): Genetics, Physiology and cut flower production. Floriculture and Ornamental Biotechnology, 6(1), 62-67.

4. Uspenskaya, M. S., \& Murashev, V. V. (2016). Hybridization in the Paeonia L. in the nature and their evolution. Bûlleten Botaničeskogo sada-instituta DVO RAN [Bulletin of Botanical Garden FEB RAS], 15, 78-79. [in Russian]

5. Uspenskaya, M. S., \& Murashev, V. V. (2019). The gene pool of wild Paeonia L. species is the basis for the creation of new generation varieties. Novosti nauki v APK [Science news in the AIC], 1-2, 101-107. doi: 10.25930/a958-y261 [in Russian]

6. American Peony Society. (n.d.). Registered peony cultivars, with a checklist of peony names, references and originators. Retrieved from https://americanpeonysociety.org/cultivars/peony-registry
7. Wu, G., Cui, L., Liu, Sh., Yao, F., Si, S, Ren, S., ... Wang, S. (2011) Preliminary Studing Report of Cultivating and Demonstrating Itoh Hybrids Introduced from Abroad. Northern Horticulture, 24, 67-71.

8. Mishchikhina, Yu. D. (2017). Cultivation of Peony IT0-Hybrids in the Middle Urals Range. Subtropičeskoe i dekorativnoe sadovodstvo [Subtropical and Ornamental Horticulture], 63, 120127. [in Russian]

9. Efimov, S. V., \& Degtyareva, G. V. (2018). Peony plant collection in the MSU Botanic Garden: an example of cooperation between fundamental and applied strategies. Lesnoj vestnik [Forestry Bulletin], 22(2), 47-54. doi: 10.18698/2542-1468-2018-247-54 [in Russian]

10. Gorobets, V. F. (2015). Piony (biologiya, selektsiya, sorta) [Peonies (biology, breeding, varieties)]. Kyiv: Veles. [in Russian]

11. Gorobets, V. F., \& Shcherbakova, T. 0. (2020). Cultivars of the Itoh Group peonies in the collection of the M. M. Hryshko National Botanical Garden National Academy of Sciences of Ukraine. Plant Var. Stud. Prot., 16(1), 17-24. doi: 10.21498/ 2518-1017.16.1.2020.201015 [in Ukrainian]

12. Osadchyi, V. I., Kosovets, 0. 0., \& Babichenko, V. M. (Eds.). (2010). Klimat Kyieva [Climate of Kyiv]. Kyiv: Nika-Tsentr. [in Ukrainian]

13. Central Geophysical Observatory named by Boris Sreznevsky. In Klimatychni dani po mistu Kyievu [Climatic data on the city of Kyiv]. Retrieved from http://cgo-sreznevskyi.kyiv.ua/index.php?fn=k_klimat\&f=kyiv [in Ukrainian]

14. Reference and information portal "Weather and Climate". In Pogoda $v$ Kieve [Weather in Kyiv]. Retrieved from http://www. pogodaiklimat.ru/monitor.php?id=33345 [in Russian]

15. Bulakh, P. E., \& Shumik, N. I. (2013). Teoriya ustoychivosti v introduktsii rasteniy [Theory of resistance in plant introduction]. Kyiv: Naukova dumka. [in Russian]

16. Shul'ts, G. E. (Ed.). (1975). Metodika fenologicheskikh nablyudeniy $v$ botanicheskikh sadakh SSSR [Methods of phenological observations in botanical gardens of the USSR]. Moscow: Publishing House of the USSR Academy of Sciences. [in Russian]

17. Kuperman, F. M. (1977). Morfofiziologiya rasteniy. Morfofiziologicheskiy analiz etapov organogeneza razlichnykh zhiznennykh form pokrytosemennykh rasteniy [Plant morphophysiology. Morphophysiological analysis of organogenesis stages of various life forms of angiosperms]. (3rd ed., rev.). Moscow: Vysshaya shkola. [in Russian]

18. Zaytsev, G. N. (1991). Matematicheskiy analiz biologicheskikh dannykh [Mathematical analysis of biological data]. Moscow: Nauka. [in Russian]

19. Reut, A. A. (2018). Results of the variety study of intersection hybrids of the genus Paeonia L. and their characteristics during introduction in the Republic of Bashkortostan. Sadovodstvo $i$ vinogradarstvo [Horticulture and Viticulture], 3, 28-34. doi: 10.25556/VSTISP.2018.3.14171 [in Russian]

20. Shevkun, A. G. (2018). Introduced varieties of intersectional hybrids of peonies in the bioresource collection of FSBSI ARHIBAN. Selekciâ i sortorazvedenie sadovyh kul'tur [Breeding and Variety Cultivation of Fruit and Berry Crops], 5(2), 62-64. [in Russian]

21. Shevkun, A. G. (2018). Peculiarities of phenological phases of intersectional hybrids of Peonies in conditions of Moscow region. Plodovodstvo $i$ âgodovodstvo Rossii [Pomiculture and small fruits culture in Russia], 55, 217-220. doi: 10.31676/2073-4948-2018-55-217-220 [in Russian]

\section{Використана література}

1. Halda J. J. The genus Paeonia. Portland, OR : Timber Press, 2004. $227 \mathrm{p}$.

2. Page M. Paeonia Itoh hybrids. The Plantsmen. 2005. Vol. 4. P. 36-39. URL: http://frosthillfarm.homestead.com/PeonyItoyblurb.pdf 
3. Kamenetsky R., Dole J. Herbaceous peony (Paeonia): Genetics, Physiology and cut flower production. Floric. Ornam. Biotechnol. 2012. Vol. 6, Sp. Iss. 1. P. 62-67.

4. Успенская М. С., Мурашев В. В. Гибридизационные процессы видов рода Paeonia L. в природе и их эволюционное значение. Бюллетень БСИ ДВО РАН. 2016. Вып. 15. С. 78-79.

5. Успенская М. С., Мурашев В. В. Генофонд дикорастущих видов Paeonia L. - основа создания сортов нового поколения. Новости науки в АПК. 2019. № 1-2. С. 101-107. doi: 10.25930/a958-y261

6 . Registered peony cultivars, with a checklist of peony names, references and originators / American Peony Society. URL: https://americanpeonysociety.org/cultivars/peony-registry.

7. Wu G., Cui L., Liu Sh. et al. Preliminary Studing Report of Cultivating and Demonstrating Itoh Hybrids Introduced from Abroad. Northern Horticulture. 2011. Iss. 24. P. 67-71.

8. Мищихина Ю. Д. Культивирование Ито-гибридов пионов в условиях Среднего Урала. Субтропическое и декоративное садоводство. 2017. № 63. С. 120-127.

9. Ефимов С. В., Дегтярева Г. В. Коллекция пионов в ботаническом саду МГУ: пример взаимодействия между фундаментальными и прикладными направлениями исследований. Лесной вестник. 2018. T. 22, № 2. С. 47-54. doi: 10.18698/2542-1468-2018-2-47-54

10. Горобец В. Ф. Пионы (биология, селекция, сорта). Киев : Велес, 2015. 160 с.

11. Горобець В. Ф., Щербакова Т. О. Сорти півоній Іто-групи (Itoh Group) у колекції Національного ботанічного саду імені М. М. Гришка НАН України. Plant Var. Stud. Prot. 2020. Т. 16, № 1. P. 17-24. doi: 10.21498/2518-1017.16.1.2020.201015

12. Клімат Києва / за ред. В. І. Осадчого, 0. О. Косовця, В. М. Бабіченко. Київ : Ніка-Центр, 2010. 320 с.
13. Кліматичні дані по місту Києву / Центральна геофізична обсерваторія імені Бориса Срезневського. URL: http://cgosreznevskyi.kyiv.ua/index.php?fn=k_klimat\&f=kyiv.

14. Погода в Киеве. Справочно-информационный портал «Погода и климат» 2004-2020. URL: http://www.pogodaiklimat. ru/monitor.php?id=33345.

15. Булах П. Е., Шумик Н. И. Теория устойчивости в интродукции растений. Киев : Наук. думка, 2013. 151 с.

16. Методика фенологических наблюдений в ботанических садах СССР / под ред. Г. Э. Шульца. Москва : Изд-во АН СССР, 1975. 27 c.

17. Куперман Ф. М. Морфофизиология растений : Морфофизиогический анализ этапов органогенеза различных жизненных форм прокрытосеменных растений. 3-е изд., доп. Москва : Высш. школа, 1977. 288 с.

18. Зайцев Г. Н. Математический анализ биологических данных. Москва : Наука, 1991. 184 с.

19. Реут А. А. Результаты сортоизучения межсекционных гибридов рода Paeonia L. и их характеристика при интродукции в Республике Башкортостан. Садоводство и виноградарство. 2018. № 3. C. 28-34. doi: 10.25556/VSTISP.2018.3.14171

20. Шевкун А. Г. Интродуцированные сорта межцекционных гибридов пионов в биоресурсной коллекции ФГБНУ ВСТИСП. Селекция и сорторазведение садовых культур. 2018. Т. 5, № 2. С. 62-64.

21. Шевкун А. Г. Особенности фенологических фаз межсекционных гибридов пионов в условиях Московской области. Плодоводство и ягодоводство России. 2018. Т. 55. С. 217-220. doi: 10.31676/2073-4948-2018-55-217-22

УДК 582.675.1:581.543

Щербакова Т. О. ${ }^{*}$, Горобець В. Ф. Фенологічні особливості росту й розвитку сортів півоній Itoh Group в умовах Національного ботанічного саду імені М. М. Гришка НАН України. Plant Varieties Studying and Protection. 2021. T. 17, № 1. C. 14-20. https://doi.org/10.21498/2518-1017.17.1.2021.228202

Національний ботанічний сад імені М. М. Гришка НАН України, вул. Тимірязєвська, 1, м. Київ, 01014, Україна, *e-mail: Shcherbacova@ukr.net

Мета. Установити особливості сезонного ритму росту й розвитку сортів півоній Itoh Group в умовах Національного ботанічного саду імені М. М. Гришка НАН України (НБС). Методи. 0б'єктом досліджень слугували рослини 24 сортів півоній Itoh Gp. Дослідження проводили на експериментальній ділянці відділу квітниководекоративних рослин НБС протягом 2017-2020 рр. Суму ефективних температур обраховували через сумування добових температур повітря, зменшених на значення біологічного мінімуму. Результати. Виділено фенологічні фази росту й розвитку рослин півоній Іто-групи. Побудовано фенологічні спектри для різних феногруп. Установлено, що цвітіння ранніх сортів - 'First Arrival', 'Hillary', 'Julia Rose', 'Morning Lilac', 'Old Rose Dandy', 'Sonoma Apricot' - розпочинається за суми ефективних температур $\geq 400{ }^{\circ} \mathrm{C}$. Сорти рослин середньої групи зацвітають, коли сума температур сягає $450{ }^{\circ} \mathrm{C}$. До цієї групи належать 'Bartzella', 'Callie's Memory', 'Cora Louise', 'Lollipop', 'Scarlet Heaven', 'Sonoma Velvet Ruby', 'Yellow Dream', 'Yellow Emperor', 'Yellow Heaven', 'Yellow Waterlily'. Пізньоквітуюча група включає сорти 'Border Charm', 'Garden Treasure', 'Kopper Kettle', 'Pastel Splendor', 'Prairie Charm', 'Viking Full Moon', 'White Emperor', 'Yankee Doodle
Dandy', необхідною умовою цвітіння яких $є$ накопичення ефективних температур понад $500{ }^{\circ} \mathrm{C}$. Висновки. Рослини сортів півоній Itoh Gp успішно проходять усі фази сезонного розвитку та встигають завершити вегетацію. За тривалістю вегетації вони належать до весняно-літньоосінньозеленого феноритмотипу. Настання відповідних фенологічних фаз у півоній досліджуваної групи сортів потребує певної суми ефективних температур. Відростання сортів розпочинається 23 березня - 2 квітня, коли сума ефективних температур змінюється в межах 20-40 ${ }^{\circ} \mathrm{C}$. Цвітіння сортів характеризується як пізньовесняне, триває 9-16 діб \pm 3-4 доби й залежить від сортових особливостей рослин та року вирощування. Швидке наростання суми ефективних температур до $700{ }^{\circ} \mathrm{C}$ під час цвітіння рослин скорочує його тривалість на 4-5 діб. Аналіз фенологічних спектрів сезонного розвитку рослин дав змогу виділити сортимент ранньо- (22-25 травня $\pm 2-3$ доби), середньо- (26-28 травня $\pm 3-5$ діб) та пізньоквітуючих (29-31 травня \pm 4-6 діб) півоній Itoh $\mathrm{Gp}$, що забезпечує безперервність їхнього цвітіння загалом упродовж двох місяців.

Ключові слова: півонії Itoh Group; фенологічні фази; сума ефективних температур.

Надійшла / Received 11.01.2021 Погоджено до друку / Accepted 18.02.2021 